\title{
COMMENT
}

DOI: $10.1057 /$ s41599-018-0103-y

\section{Future cities: renarrating human agency}

\author{
Robert Cowley (1) ${ }^{1}$
}

\begin{abstract}
The media coverage of Hurricane Harvey's impact on the city of Houston in August 2017 reveals an 'Anthropocenic' sensibility, which tends to deny our ability to solve pressing environmental and social problems through strong and direct human action. This sensibility is reflected at city level in new forms of governance, exemplified here with reference to resilience, smart urbanism, and design-thinking. These have in common a cautious, inductive logic of change; their limited imaginations of space and time imply a dispersed sense of human agency. But if these new rationalities are unlikely to yield convincing solutions to problems such as Hurricane Harvey, perhaps there is a need to rethink the dominant framing of the Anthropocene, which underpins them.
\end{abstract}

\footnotetext{
${ }^{1}$ King's College London, London, UK. Correspondence and requests for materials should be addressed to R.C. (email: robert.cowley@kcl.ac.uk)
} 


\section{Harvey meets Houston}

'Hurricane Harvey' made landfall in the Southern United States at the end of August 2017. Such was the unprecedented intensity of resulting rainfall that the US National Weather Service introduced new colours into maps recording its progress. Across the state of Texas, tens of people died, and hundreds of thousands of homes were engulfed by floodwater, with the city of Houston particularly affected. Early estimates of its economic cost ranged from $\$ 70$ bn to as much as $£ 300 b n .^{1}$

\section{T}

he media frenzy accompanying Hurricane Harvey's arrival in Houston (illustrated by apocalyptic imagery of parts of the city under deep water) may seem unsurprising, given the storm's ferocity. While many commentators noted the relatively sparse coverage of other recent Asian flooding events, often worse in their human toll, Harvey's effects were still so unusual in their local context as to constitute a '1000-year flood event' (Samenow, 2017). Climatologists' confirmation of a probable causal link between global warming and the extremity of the associated rainfall (Risser and Wehner, 2017; van Oldenborgh et al., 2017) have been widely reported, fuelling ominous predictions that similarly unusual weather events will become commonplace in the near future (Carrington, 2017). Harvey, then, has been narrated as bringing us face-to-face with the catastrophic implications of our collective failure to tackle climate change.

The media coverage was enlivened further by the fact that Houston specifically was the prime victim of the storm. In what Braje (2015) calls the 'court of public opinion' on climate-related matters, the stories of this urban weather event often appeared to have the qualities of parables, in which Houston symbolised the hubris of modernity. One account in the New York Times, for example, drawing on 'limits to growth' discourse (Dryzek, 2005), alluding to the myth of the Tower of Babel, and noting Houston's importance for fossil fuel production, painted the hurricane as having:

inundated a city perpetually looking to the future, a place built on boundless entrepreneurialism, the glories of air conditioning, a fierce aversion to regulation and a sense of limitless possibility.

The result has been a uniquely American success story, the capital of the world's petroleum industry, and the place that sent a man to the moon, built the world's biggest medical centre and became a model of dizzying multiculturalism, with 145 languages spoken.

But Harvey's staggering flooding is raising very unHoustonian questions about whether there are, in fact, limits to the Houston model of perpetual growth, and whether humans can push nature only so far before nature pushes back with catastrophic force. (Fernandez and Fausset, 2017).

This and other media narratives, it would seem, were eager to position Houston's fate as revealing the failure and limits of modernity: no longer, we are warned, can we afford to think of the 'natural world' as straightforwardly 'out there'. In effect, Hurricane Harvey was cast as a reminder that we now live in the 'Anthropocene', whereby 'the reunion... between human agency and non-human agency...gives the lie to th[e]-temporal, ontological, epistemological, and institutional-great divide between nature and society that widened in the nineteenth and twentieth centuries' (Bonneuil and Fressoz, 2016: p 32). Nor can we cling to the illusion, rooted in the colonial era, that 'more advanced' societies are relatively immune to the ' 'external' influences of the environment on human history' (ibid: p 31).

Of course, some commentators made the opposite case. The Spectator, for example, observed that Houston's motorways are specifically designed to disperse floodwater, and praised the emergency services, to paint the events as a triumph of modernity: 'This is the story of human development: when a nation grows more prosperous, it is less at the mercy of the elements' (Darwall and Nelson, 2017). Nevertheless, the very need to assert this position highlights the existence of contemporary contestations around modernity: the encounter between Harvey and Houston provided a narrative backdrop against which these contestations were played out.

At the same time, Houston played an ambiguous role in this story. Its 'fierce aversion to regulation' asserted in the New York Times (see above) also hints at its rather different symbolic charge, as the 'poster child for sprawl' (Lewyn, 2005). In a separate and well-established tradition, Houston is mobilised as the paradigmatic 'unplanned' Western city (Sudjic, 1993: p 103): in shunning planning, it rejects the 'quintessentially modernist notion that socio-spatial phenomena are amenable to some form of monitoring and control' (Karadimitriou, 2010: p 425). Instead, it is held to exemplify a laissez-faire privileging of market forces in urban development (Qian, 2010). Within this complementary storyline, it is precisely the rejection of modernist state-centric normativity that has led to environmental unsustainability; and to spatialised forms of injustice that have been exposed and exacerbated by Hurricane Harvey (Democracy Now, 2017).

In fact, it is far from self-evident that Houston is straightforwardly 'unplanned'. Sudjic (1993: p 103) contested that 'is in fact nothing of the kind...it has an armoury of regulations that achieve very much the same ends': rather than emerging organically, its urban form is strictly policed through restrictive covenants, rather than planning based on zoning. More recently, Lewyn (2005) has rejected the received interpretation of Houston, arguing that its sprawl has been caused precisely by rules over minimum lot sizes, minimum number of parking spaces, and the like. But all this only underlines the discursive importance of Houston, as a canvas on which different (often dystopian) scenarios of the urban future are enacted in the popular imagination. It illustrates the dilemma posed by an 'Anthropocenic' sensibility, whereby our growing unwillingness to be unreflexively modern appears to rob us of the human agency required to tackle overwhelming problems such as climate change.

This dilemma is evident in the directly relevant field of water management, where it is now widely accepted that climate change has undermined an older assumption of 'stationarity', whereby 'natural systems fluctuate within an unchanging envelope of variability' (Milly et al., 2008: p 573). Dealing with the new reality of 'non-stationary' water events raises daunting challenges for scientists and policy-makers, given the complexity of patterns of change, high levels of uncertainty, and a rapidly shifting knowledge base (ibid.). But whether or not the 'natural world' has changed, the stories that we tell about it have done: thought of as a sensibility, 'non-stationarity' undermines our confidence or willingness to act 'on' the external world, by disrupting our understanding of human agency.

The following section briefly posits three examples of how this shift in sensibility is reflected in urban policy-making specifically. These relate to: the rising prominence of 'resilience' within sustainable development discourse; the growing appeal of 'smart' governance ideals alongside representative institutional processes; and the rise of 'design-thinking' where plans might once have been made. And in order to think about the implications of this shift for cities of the future, some differences are proposed 
between the ways these older and newer governance approaches imagine space and time.

\section{Urban policy stories old and new}

First, it is striking that 'resilience' discourse has become widespread within more established bodies of thinking around urban sustainability: indicatively, the UN's 11th Sustainable Development Goal aims to 'Make cities and human settlements inclusive, safe, resilient and sustainable' (UN, 2016). But this accommodation conceals a deep tension. The spatial imagination of sustainable development is one of long-distance responsibilities; resilience, by contrast, is inward-looking, focused on defending the local against shocks from afar (Joss, 2015). While sustainable development asserts a responsibility for the long-term future, the temporal modality of resilience is one of ongoing iterations, internal feedback loops and 'bouncing back'. Sustainable development aspires to pre-empt disaster; resilience is oriented more towards reactivity and adaptation.

In parallel, liberal democratic ideals of urban policy-making that prioritise representation, deliberation, and normative decision making, increasingly sit alongside a focus on digital technology-enabled 'smart urbanism' (see e.g. Marvin et al., 2016). Mainstream visions of the smart city appeal to policymakers because they promise efficiency-financially, and in terms of resource uses and governance processes (Cowley et al., 2017). The imaginary space of sensors, big data, and algorithmic governance is not that of the polis, but rather of the city as endlessly 'becoming'. Citizens are given a voice through what they do, rather than what they say. Space that is knowable, collectively owned, and created in our image, is reimagined as a system of systems, produced through aggregations of individual actions, and entangled with, rather than only shaped by, our actions. Big data-driven algorithms do not produce a future of alternative pathways and scenarios, amenable to shaping, and divided by critical junctures: instead, they conjure up an 'extended present' (Nowotny, 1994), continually emerging in unpredictable ways.

This 'non-representational' (Thrift, 2008) imagination of city space raises questions over the status of 'planning' more generally. The evident failures of grand twentieth-century modernist planning (in the economic, environmental, and urban spheres) have left the concept 'under a shadow' (Giddens, 2009: p 95) and 'ideologically contaminated' (Urry, 2016: p 12). In this context, it has been suggested elsewhere (Cowley, 2017) that 'design thinking' has colonised multiple arenas where 'planning' might traditionally have held sway. But design-thinking is characteristically cautious: Latour contrasts the designer with the 'heroic, Promethean, hubristic dream of action' (Latour, 2011: p 3), such that 'the more we think of ourselves as designers, the less we think of ourselves as modernisers' (Latour, 2011: p 3). Designing evokes a dispersed sense of agency: in place of hierarchical power, or primary agency being gathered in and disseminated from a representative centre, design solutions emerge through processes of co-creation, with porous boundaries between designer, context, and user (Cowley, 2017). Planning's spaces are defined spheres to be 'acted on'; for the designer, space co-constitutes and productively constrains outcomes. While plans imagine a linear future, design-like resilience-has explicitly iterative rhythms.

Taken together, then, these three urban governance tendencies tend to repel representations of space, and exhibit non-linear temporal logics. This double rejection of modernity makes them well attuned with a broader Anthropocenic sensibility. In turning away from the idea that the future of urban space is ours to forge, they place their hopes on solutions emerging from this space over time. The shift is captured well by Maarten Hajer's observation (with reference to the rise of 'experimentalism' in urban policy- making and development) that 'a deductive logic seems to have given way to a far more inductive way of reasoning' (Hajer, 2016: p xix).

But this inductive orientation may also involve a fetishisation of ideals of efficiency and ongoing innovation, at the expense of norms of 'good' and 'bad'-an outcome characterisable by what anthropologist Elizabeth Povinelli (2016: p 148), in a different context, calls an 'anti-normative normativity'. It places faith in pragmatic reactivity, rather than in a morally normative future punctuated by considered choices, decisions, and strong human agency. Its primary aim is not to clarify and act on goals, but rather to enable processes. Or, more precisely, the process is the goal.

\section{Concluding remarks}

There is no intention here to suggest that advocates and practitioners of resilience, smart governance, or design-thinking are deluded, or somehow pose a threat to the urban future. Far from it: constructive attempts to overcome the failures of modernity are to be welcomed. We may optimistically see these new approaches to urban governance as in productive tension with more established ones, rather than as a challenge to them. Their implications for the future of cities are intentionally uncertain. And rather than interpreting them as an abnegation of state responsibility in wealthy parts of the world, we might highlight their practical value for cities lacking the institutional capacity or resources to implement bold, large-scale transformational projects. Nevertheless, given their recent ascendancy, it seems worth remembering that such 'stories' are not the only ones that might be told.

Whether or not they constitute suitable responses to the dilemma of the Anthropocene, the latter is not a neutral conceptual lens. Rather, the particular ways in which we narrate and frame this dilemma have implications for understandings of responsibility and agency, shaping expectations and criteria for regulation (Berkhout, 2014). One particular risk is that a reductive singular grand narrative of planetary change, supported by scientific graphs demonstrating its 'Great Acceleration', has had a depoliticising effect (Bonneuil and Fressoz, 2016). The resulting fatalism, underpinned by a sensibility of increasing global complexity (Healey, 1997; Rosenau, 2000), is only amplified by the use of apocalyptic imagery in the popular media (Crist, 2013). This singular, 'bad' Anthropocene leaves us unable to imagine or understand what 'good' future pathways might look like (Berkhout, 2014; Kunnas, 2017). But if this framing is not an inevitable one, then neither is an outcome whereby, in the face of problems on the scale of Hurricane Harvey, agents of urban change are embracing governance rationalities characterised primarily by caution, and a limited sense of human agency.

In this sense, there is good reason to listen to the growing chorus of writers who variously alert us to the possibility that we might think in new-if as yet unknown-more responsible ways about human agency. Hamilton (2017), for example, proposes that the Anthropocene does not dilute human agency, but rather indicates both a 'multiplication of human power and an activation of dormant forces in the Earth System'. Malm (2018) accepts that the Anthropocene describes new and novel forms of interaction between society and nature, but rejects the implication that human 'intentional' agency should, therefore, be collapsed into all other types of causality. For Chandler (2018), new modes of governance, which appear to 'affirm' the decentring of the human are not inevitable responses to the Anthropocene. Rather, they might be usefully contested, based on an identification of their particular underlying claims. 
The significance of such discussions-whether or not we buy into these particular authors' broader agendas-is to remind us that alternative ways of thinking are possible, which neither return to modernity's hubris, nor revel in 'posthuman' impotence. If, in other words, our current collective thinking only leaves us unable to respond effectively to glaring environmental and social problems, then perhaps we need a new set of stories.

Received: 26 October 2017 Accepted: 26 March 2018

Published online: 10 April 2018

\section{Notes}

1 see e.g. Quealy, 2017; Wood, 2017.

\section{References}

Berkhout F (2014) Anthropocene futures. Anthr Rev 1(2):154-159

Bonneuil C, Fressoz J-B (2016) The shock of the Anthropocene: The earth, history and us. Verso Books, London

Braje TJ (2015) Earth systems, human agency, and the Anthropocene: Planet earth in the human age. J Archaeol Res 23(4):369-396

Carrington D (2017) Global warming made Hurricane Harvey deadly rains three times more likely, research reveals. The Guardian, 13 December. Online: https://www.theguardian.com/us-news/2017/dec/13/global-warming-madehurricane-harvey-deadly-rains-three-times-more-likely-research-shows (Accessed 30 Jan 2018).

Chandler D (2018) Ontopolitics in the Anthropocene: an introduction to mapping, sensing and hacking.. Routledge, London

Cowley R (2017) Resilience and design: an introduction. In: Cowley R, Barnett C, Katzschner T, Tcazc N and De Boeck F (eds) Forum: resilience and design. Resilience: International policies, practices and discourses 6(1):1-34

Cowley R, Joss S, Dayot Y (2017) The smart city and its publics: insights from across six UK cities. Urban Res \& Pract 11(1):53-77

Crist E (2013) On the poverty of our nomenclature. Environ Humanit 3 (1):129-147

Democracy Now (2017) Will Houston's post-harvey recovery exacerbate inequities or build a more just city? 5 September. Online: https://www.democracynow. org/2017/9/5/will_houston_s_post_harvey_recovery (Accessed 15 Oct 2017)

Darwall R and Nelson F (2017) Resilience, not devastation, is the real story of the Texas floods: Houston's response to Hurricane Harvey is a lesson for the world. The Spectator, 2 September. Online: https://www.spectator.co.uk/ 2017/09/resilience-not-devastation-is-the-real-story-of-the-texas-floods/ (Accessed 22 Oct 2017)

Dryzek J (2005) The politics of the earth: Environmental discourses. Oxford University Press, Oxford

Fernandez M \& Fausset R (2017) A storm forces Houston, the limitless city, to consider its limits. New York Times, 30 August. Online: https://www.nytimes. com/2017/08/30/us/houston-flooding-growth-regulation.html (Accessed 15 Oct 2017)

Giddens A (2009) The politics of climate change. Polity Press, Cambridge

Hajer M (2016) Foreword. In: Evans J, Karvonen A, Raven R (eds) The experimental city. Routledge, Abingdon, pp. xvii-xix

Hamilton C (2017) Defiant earth: The fate of humans in the Anthropocene. Polity Press, Cambridge

Healey P (1997) Collaborative planning: Shaping places in fragmented societies. Macmillan, Basingstoke

Joss S (2015) Sustainable cities: Governing for urban innovation. Palgrave Macmillan, London

Karadimitriou N (2010) Cybernetic spatial planning: steering, managing or just letting go? In: Hillier J, Healey $\mathrm{P}$ (eds) The Ashgate research companion to planning theory: Conceptual challenges for spatial planning. Farnham, Ashgate, pp 425-446

Kunnas J (2017) Storytelling: From the early Anthropocene to the good or the bad Anthropocene. Anthr Rev 4(2):136-150

Latour B (2011) A cautious prometheus? A few steps toward a philosophy of design with special attention to Peter Sloterdijk. In: Schinkel W, Noordegraaf-Eelens L (eds) In Medias Res: Peter Sloterdijk's spherological poetics of being. Amsterdam University Press, Amsterdam, pp. 151-164

Lewyn M (2005) How overregulation creates sprawl (Even in a city without zoning). Wayne Law Rev 50:1171-1208
Malm A (2018) The progress of this storm: On the dialectics of society and nature in a warming world. Verso Books, London

Marvin S, Luque-Ayala A, McFarlane C (2016) Smart urbanism: Utopian vision or false dawn? Routledge, London

Milly PC, Betancourt J, Falkenmark M, Hirsch RM, Kundzewicz ZWD, Lettenmaier DP, Stouffer RJ (2008) Stationarity is dead: Whither water management? Science 319(5863):573-574

Nowotny H (1994) Time: The modern and the postmodern experience. Polity Press, Cambridge

Qian Z (2010) Without zoning: Urban development and land use controls in Houston. Cities 27(1):31-41

Quealy K (2017) The cost of Hurricane Harvey: Only one recent storm comes close. New York Times, 1 September. Online: https://www.nytimes.com/ interactive/2017/09/01/upshot/cost-of-hurricane-harvey-only-one-stormcomes-close.html (Accessed 16 Oct 2017)

Risser MD, Wehner MF (2017) Attributable human-induced changes in the likelihood and magnitude of the observed extreme precipitation during Hurricane Harvey. Geophys Res Lett 44:12457-12464

Rosenau JN (2000) Change, complexity, and governance in a globalizing space. In: Pierre J (ed) Debating governance: Authority, steering and democracy. Oxford University Press, Oxford, pp. 167-200

Samenow J (2017) Harvey is a 1,000-year flood event unprecedented in scale Washington Post, 31 August. Online: https://www.washingtonpost.com/ news/capital-weather-gang/wp/2017/08/31/harvey-is-a-1000-year-floodevent-unprecedented-in-scale/?utm_term $=. e 160405 a 355 a$ (Accessed 15 Oct 2017)

Sudjic D (1993) The 100 Mile City. Flamingo, London

Thrift N (2008) Non-representational theory: space |politics affect. Routledge, Abingdon

UN (2016) Sustainable development goal 11. Online: https:// sustainabledevelopment.un.org/sdg11 (Accessed 22 Oct 2017)

Urry J (2016) What is the future? Polity Press, Cambridge

van Oldenborgh GJ, van der Wiel K, Sebastian A, Singh R, Arrighi J, Friederike Otto F, Haustein K, Li S, Vecchi G, Cullen H (2017) Attribution of extreme rainfall from Hurricane Harvey, August 2017. Environ Res Lett 12 (12):124009

Wood Z (2017) Economic cost of Hurricane Irma "could reach \$300bn". The Guardian, 10 September. Online: https://www.theguardian.com/business/ 2017/sep/10/economic-cost-of-hurricane-irma-could-reach-300bn (Accessed 16 Oct 2017)

\section{Acknowledgements}

This work was supported by the Economic and Social Research Council (grant number ES/L015978/1).

\section{Additional information}

Competing interests: The author declares no competing financial interests.

Reprints and permission information is available online at http://www.nature.com/ reprints

Publisher's note: Springer Nature remains neutral with regard to jurisdictional claims in published maps and institutional affiliations.

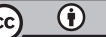

Open Access This article is licensed under a Creative Commons Attribution 4.0 International License, which permits use, sharing, adaptation, distribution and reproduction in any medium or format, as long as you give appropriate credit to the original author(s) and the source, provide a link to the Creative Commons license, and indicate if changes were made. The images or other third party material in this article are included in the article's Creative Commons license, unless indicated otherwise in a credit line to the material. If material is not included in the article's Creative Commons license and your intended use is not permitted by statutory regulation or exceeds the permitted use, you will need to obtain permission directly from the copyright holder. To view a copy of this license, visit http://creativecommons.org/ licenses/by/4.0/.

(c) The Author(s) 2018 